\title{
Effect of Extracellular Metabolites of Trichoderma pseudokoningii on Radial Growth of Fusarium oxysporum, Colletotrichum capsici, Rhizoctonia solani and Sclerotinia sclerotiorum
}

\author{
Pranab Dutta*, P. Bhowmick and S. Boruah \\ Department of Plant Pathology, Assam Agricultural University, Jorhat-785013, Assam, India \\ *Corresponding author
}

\begin{abstract}
A B S T R A C T

\begin{tabular}{|c|}
\hline Keywords \\
\hline $\begin{array}{l}\text { Trichoderma, Culture } \\
\text { filtrate, Biocontrol, } \\
\text { Colletotrichum, } \\
\text { Fusarium, Rhizoctonia, } \\
\text { Sclerotinia, Radial } \\
\text { growth }\end{array}$ \\
\hline Article Info \\
\hline $\begin{array}{l}\text { Accepted: } \\
10 \text { December } 2017 \\
\text { Available Online: } \\
10 \text { January } 2018\end{array}$ \\
\hline
\end{tabular}

\section{Introduction}

Trichoderma has long been considered as one of the most promising biocontrol agent for several plant pathogens. Numerous authors have reported the use of Trichoderma as a biocontrol agent against many soil borne plant pathogens. Now days the indiscriminate use of many different pesticides has led to a serious concern from the environmental point of view. There are numerous reports on the non-target effect of soil chemical treatment on the biocontrol agents Trichoderma and Gliocladium spp. (Munnecke, 1972; Rodriguez kabana and Curl, 1980; Cook and
\end{abstract}

Baker, 1983). The biocontrol potential of Trichoderma has been indicated in a no. of reports (Kehri and Chandra, 1991; Elad et al., 1986; Jeyarajan et al., 1991). Based on many reports a dominating idea prevails that anything biological is always safe from the environmental point of view and so is found in case of biological control of plant pathogens in vitro as well as in vivo. Trichoderma spp. has been recognized as a source of various cell wall degrading enzymes and secondary metabolites (Vinale, 2008; Anita et al., 2012). Trichoderma is able to secret 40 different secondary metabolites that may contribute to their mycoparasitism and antibiotic action 
(Sivasithamparam and Ghisalberti, 1998). The extracellular enzymes secreted by Trichoderma such as chitinolytic and glucanolytic enzymes degrades the cell wall and play a role in biological control through mycoparasitism (Ratnakumari et al., 2011). The culture filtrates when found effective against pathogens can be developed into biopesticides with desirable properties and can be effectively employed for management of different pathogens. Trichoderma strains are reported to be effective as biocontrol agents due to their high reproductive capacity, ability to survive under highly infavourable conditions, efficiency in the utilization of nutrients, capacity to modify the rhizosphere, strong aggressiveness against phytopathogenic fungi and efficiency in promoting plant growth and defense mechanisms (Benitez et al., 2004).

\section{Materials and Methods}

\section{Isolation of Trichoderma spp.}

Trichoderma spp. was isolated following the method given by Mishra et al., (2011). One gram of the soil sample was taken and added to $1 \mathrm{ml}$ of sterilized distilled water to make a dilution of $10^{-1}$. This suspension was then subjected to serial dilutions and a dilution of $10^{-5}$ was attained. One milliliter of each dilution viz., $10^{-3}$ to $10^{-4}$ was poured on to Trichoderma Specific Medium (TSM) and purified by single spore method. They were identified on the basis of their morphological characters. Cultures were identified according to conidiophore, shape of the phialides and emergence of phialophores and phialospores. The purified and identified cultures of Trichoderma spp. were maintained on Potato Dextrose Agar (PDA) medium and stored at $4^{\circ} \mathrm{C}$ for further use. From the isolated Trichoderma spp., Trichoderma pseudokoningii was used to study its bioefficacy against different pathogens.

\section{Isolation of pathogens}

The pathogens viz., Rhizoctonia solani, Sclerotinia sclerotiorum, Fusarium oxysporum and Colletotrichum capsici were isolated from the diseased samples collected from the field and nursery plots. All the pathogens were isolated using a single same protocol for all i.e. pure culture isolation and later on using hyphal tip culture method.

The diseased samples from the field and nursery were brought to the laboratory and washed thoroughly with clean water. Then the diseased portions were separated from the sample and are rinsed with distilled water before being taken to the inoculation chamber.

The diseased specimens were cut into small pieces and then surface sterilized with $0.5 \%$ sodium hypochlorite $\left(\mathrm{NaOCl}_{2}\right)$ for 2 minutes which were subsequently rinsed well with three changes of sterile distilled water. The sterilized pieces were then transferred to potato dextrose agar medium and incubated at $28 \pm 1^{\circ} \mathrm{C}$. The pure culture of the pathogens was then obtained by isolating the fungus by hyphal tip culture.

\section{Extraction of extracellular metabolites from Trichoderma pseudokoningii}

The extraction of extracellular metabolites of Trichoderma psuedokoningii was done on Czapek dox broth medium (Distilled water: 1000ml, Sucrose: 30 g, Dipotassium phosphate: $1 \mathrm{~g}$ Potassium chloride: $0.5 \mathrm{~g}$, Sodium nitrate: $3 \mathrm{~g}$, Magnesium sulphate: $0.5 \mathrm{~g}$, Ferrous sulphate: $0.01 \mathrm{~g}, \mathrm{pH}: 7.3 \pm 0.2$ ). Fifty (50) $\mathrm{ml}$ of CDB medium were prepared on $100 \mathrm{ml}$ conical flasks.

Then $1 \mathrm{ml}$ of spore suspension of $T$. pseudokoningii $\left(10^{5} \mathrm{cfu} / \mathrm{ml}\right)$ was inoculated in the medium from 7 day old culture. The inoculated broth culture was then filtered 
through Whatman no. 1 and10. The filtrate was then centrifuged at $10,000 \mathrm{rpm}$ at $4^{\circ} \mathrm{C}$ for 15 minutes. Then the culture filtrate was passed through Whatman no. 42 for sterilization.

\section{Preparation of different concentrations of the CDA medium}

Different concentrations of CDA (Distilled water: $1000 \mathrm{ml}$, Sucrose: $30 \mathrm{~g}$, Dipotassium phosphate: $1 \mathrm{~g}$, Potassium chloride: $0.5 \mathrm{~g}$, Sodium nitrate: $2 \mathrm{~g}$, Magnesium sulphate 0.5g, Ferrous sulphate: $0.01 \mathrm{~g}$, Agar-Agar: 15 g, pH: $7.3 \pm 0.2$ ) medium amended with $T$. pseudokoningii culture filtrate were prepared at doses $0 \%, 5 \%, 10 \%, 15 \%$ and $20 \%(\mathrm{v} / \mathrm{v})$ cocncentration.

In each petriplate $20 \mathrm{ml}$ media amended with required doses of $T$. pseudokoningii culture filtrate was poured. Pathogen inoculated on CDA medium without any culture filtrate was kept as control.

\section{Screening of $T$. pesudokoningii isolate against the pathogens}

The petriplates poured with amended media were inoculated with $5 \mathrm{~mm}$ mycelial disc of each pathogen cut with the cork borer. For each concentration three replications were made for each of the pathogen. Then the plates were incubated at $28 \pm 1^{\circ} \mathrm{C}$. Periodical observation at 24 hours was made and data were recorded by measuring the colony diameter of the treated plates as well as the control. The mycelial growth inhibition was calculated by the following formula:-

$$
\text { (DC - DT) }
$$

Mycelial growth inhibition $(\%)=-\frac{-----X}{\text { DC }} 100$

Where, $\mathrm{DC}=$ fungal colony diameter in control set and DT = Fungal colony diameter in treatment set.

\section{Results and Discussion}

\section{Isolation of Trichoderma isolate}

The biocontrol agent $T$. pseudokoningii was isolated in TSM (Trichoderma selective medium). The isolate which was recognized as T. pseudokoningii produced typical symptoms i.e. typical morphological as well as cultural characters. The characteristic of $T$. pseudokoningii such as colony appearance and sporulation pattern were examined after growing on PDA medium.

Microscopic observations of conidiophores and conidia were made and measurements were taken after slide preparation of the culture in clean grease free slide stained with lactophenol- cotton blue. On Potato dextrose agar medium $T$. pseudokoningii formed white and transparent mycelia with little or no conidia production at first. Later on the conidia formed by $T$. pseudokoningii were pale green in colour and measured around 2.3 $\times 2.6 \mu \mathrm{m}$. The phialides of $T$. pseudokoningii arised singly and laterally and the complete reproductive structure was observed as single.

\section{Isolation of pathogens}

For isolation of the pathogens at first the diseased specimens were collected based upon the typical symptoms observed that are produced by the pathogens. Specific disease symptoms such as sheath blight of rice, root rot, anthracnose and white mold of French Bean were collected to get the specific causal agent. Then each of the pathogen was isolated following hyphal tip culture method to get the pure culture. The characteristics of the pathogens were then studied for their confirmation. Pathogens such as Rhizoctonia solani, Sclerotinia sclerotiorum, Fusarium oxysporum and Colletotrichum capsici were isolated and were studied in the experiment against $T$. pseudokoningii. 
Effect of extracellular metabolites (cell free culture filtrate) of $T$. pseudokoningii by dual culture method with the pathogens

In obvious way it was found that Trichoderma has a dominating role over many plant pathogens including the pathogens used in the current experiment. Satisfactory result was found when the cell free culture filtrates of $T$. pseudokoningii were added to the pathogens at different rates of concentrations. The best effect of culture filtrate was observed in Colletotrichum capsici where higher mycelia growth inhibition was found in nearly all the concentrations. The mycelia growth inhibition of C. capsici was found to be $65.54 \%$, $69.63 \%, 55.08 \%$ and $65.01 \%$ at $5 \%, 10 \%$, $15 \%$ and $20 \%$ concentrations respectively. At $0 \%$ percent concentration the plate was fully covered by the pathogen. The second best effect of the culture filtrates was found against the pathogen Sclerotinia sclerotiorum where the mycelial growth inhibition was $0 \%$, $45.72 \%, 64.15 \%, 58.67 \%$ and $62.82 \%$ at 0,5 , 10,15 and $20 \%$ concentration respectively whereas at $5 \%$ concentration $41.10 \%$, at $10 \%$ 55.62 , at $15 \% \quad 47.55$ and at $20 \% 50.22 \%$ reduction in mycelia growth was observed against the pathogen $R$. solani. Fusarium oxysporum showed the lowest reduction in mycelial growth when grown in the media amended plate. The growth inhibition was observed at $0 \%, 31.57 \%, 36.10 \%, 36.25 \%$ and $34.53 \%$ at $0,5,10,15$ and $20 \%$ concentration. However, an inhibitory effect of the bioagent was found against the pathogen when the media was treated with cell free culture filtrate (Table 1).

Table.1 Effect of cell free culture filtrate of T. pseudokoningii on growth inhibition of different pathogens

\begin{tabular}{|c|c|c|c|c|}
\hline \multirow{2}{*}{$\begin{array}{l}\text { Concentration of } T \text {. } \\
\text { pseudokoningii culture filtrate } \\
(\%)\end{array}$} & \multicolumn{4}{|c|}{ Percent mycelial growth inhibition of pathogens $(\%) *$} \\
\hline & R.solani & S. sclerotiorum & F. oxysporum & C. capsici \\
\hline 0.0 & 0.00 & 0.00 & 0.00 & 0.00 \\
\hline 5.0 & 41.10 & 45.72 & 31.57 & 65.54 \\
\hline 10.0 & 55.62 & 64.15 & 35.76 & 69.63 \\
\hline 15.0 & 47.55 & 58.67 & 36.25 & 55.08 \\
\hline 20.0 & 50.22 & 62.82 & 34.53 & 65.01 \\
\hline
\end{tabular}

Plate.1 Pure culture T. pseudokoningii

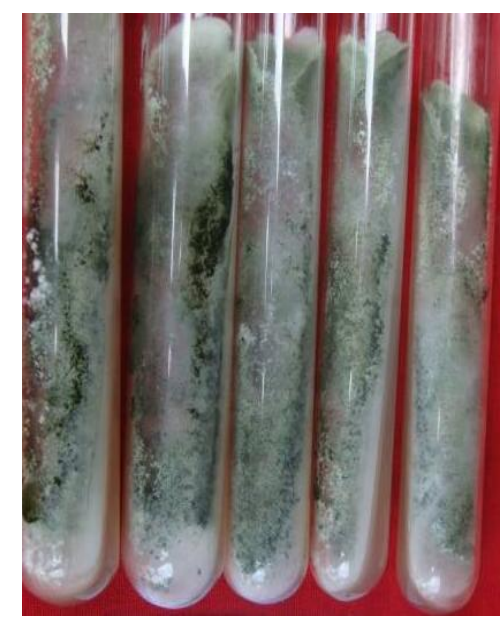




\section{Plate.2 Radial growth of of Colletotrichum capsici at different concentration of culture filtrate of $T$. pseudokoningii}
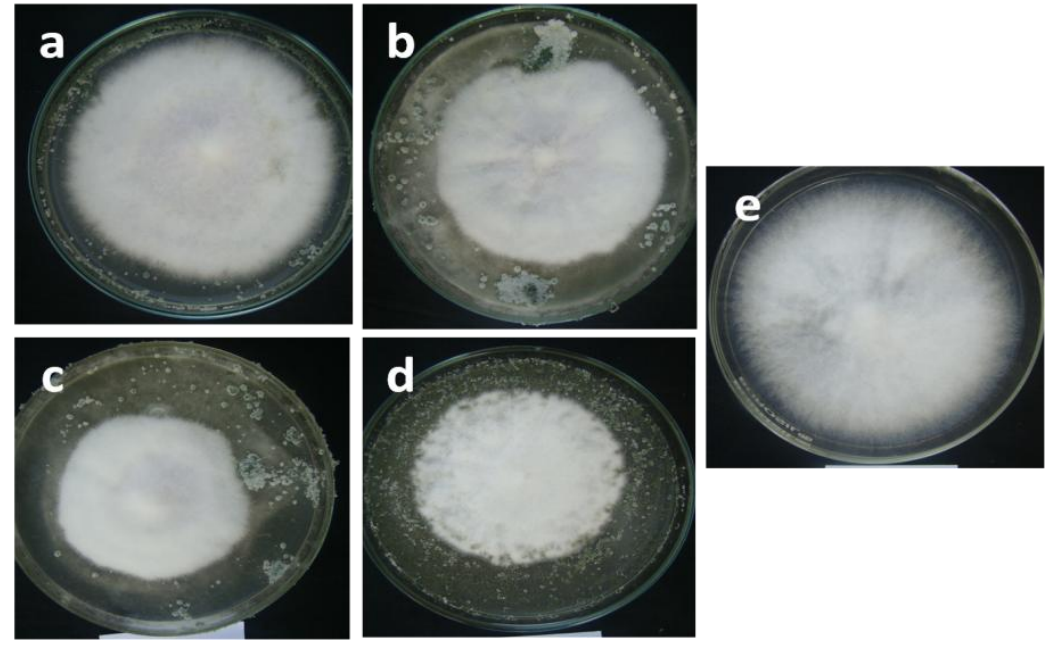

a. $5 \%$, b. $10 \%$, c. $15 \%$, d. $20 \%$, d. Control

Thus, the finding of these experiments is in agreement with many workers who have also reported the inhibitory effect of culture filtrate of Trichoderma upon several plant pathogens. Mishra., 2011 reported that more than 50\% growth inhibition was found at $10 \%$ cell free culture filtrate of $T$. viride against pathogens like $R$. solani, S. rolfsii, M. phaseolina and $C$. capsici while at $20 \%$ concentration $100 \%$ mycelial growth inhibition was observed which suggest the inhibitory action of cell free culture filtrate of Trichoderma as found in the present experiment. But Bokhari and Parveen, 2012 found that culture filtrates of $T$. harzianum and $T$. viride caused reduction in the growth of Fusarium solani by 21.3 and $17.3 \%$ only respectively. Anita et al., 2012 reported that presence of certain compounds such as $\mathrm{N}$ phenylethylenediamine, phenol, pthalic acid, diallylamine and propanal in Trichoderma spp. perhaps serves the antagonist for survival function by competing against the pathogen. Prasad and kumar, 2011 also reported that the antagonist Trichoderma produced non-volatile anti-fungal antibiotics and observed radial growth inhibition of $R$. solani. The undiluted culture filtrates of $T$. harzianum Rifai and $T$. pseudokoiningii Rifai showed varying degree of inhibition of spore germination. $T$. pseudokoningii culture filtrate had a moderate to strong inhibitory effect on mycelia of the rot pathogens (Odebode, 2006). So by looking into several reports it can be said that experiments conducted by studying the extracellular metabolites of Trichoderma spp. gives positive results with a view point of controlling the growth of pathogens in in vitro conditions.

This is an era which demands more precautionary measures right from a single beneficial insect to human beings due to the toxic nature of chemicals which are released in one or a several ways into our environment. So new methods and technologies should be developed for utilizing the different metabolites released by the biocontrol agents and their subsequent injection into crop protection measures in nurseries as well as in field levels.

\section{Acknowledgement}

The author acknowledged DST, Govt of India for funding to carry out the research work. The suggestion, guidance and interest of Dr. G. N. Hazarika, Director of Research (Agri), Dr. K. C. Puzari, Prof and Head, Department of Plant Pathology, Assam Agricultural University, Jorhat and Dr. M. S. Rao, Principal Scientist, 
IIHR, Bengalore is also greatly acknowledged.

\section{References}

Anita, S., Ponmurugan, P and Ganesh Babu, R. 2012. Significance of secondary metabolites and enzymes secreted by Trichoderma atroviride isolates for the biological control of Phomopsis canker disease. African Journal of Biotechnology. 11(45): 10350-10357.

Benitez, T., Rincon, A.M., Limon, M.C. and Codon, A.C. 2004. Biocontrol mechanisms of Trichoderma strains. Intern. Microbiol. 7(4): 249-260.

Bokhari, N.A. and Perveen, K. 2012. Antaonistic action of Trichoderma harzianum and Trichoderma viride against Fusarium solani causing root rot of tomato. African Journal of Microbiology Research. 6(44): 71937197.

Cook, R.J. and Baker, K.F. 1983. The nature and practice of biological control of plant pathogens. Amer. Phytopathol. Soc., St. Paul, MN.

Elad, Y., Zvieli, Y. and Chet, I. 1986. Biological control of Macrophomina phaseolina (Tassi) Goid by Trichoderma harzianum. Crop Protecion. 5: 288-292.

Jeyarajan, R. Ramakrishnan, G. Rajamanickam, B. and Sangeetha, P. 1991. Field demonstration of efficacy of Trichoderma as biocontrol agent for root rot disease of grain legumes and oilseeds. Petria, 1: 143.

Kehri, H.K. and Chandra, S. 1991. Antagonism of Trichoderma viride to Macrophomina phaseolina in the control of dry root rot of mung. Indian Phytopath. 44: 60-63.

Mishra, B.K., Mishra, R.K., Mishra, R.C.,
Tiwari, A.K., Yadav, R.S. and Dikshit, A. 2011. Biocontrol efficacy of Trichoderma viride isolates against fungal plant pathogens causing disease in vigna radiata L. Archives of Applied Science Research. 3(2): 361-369.

Munnecke, D.E. 1972. Factors affecting the efficacy of fungicides in soil. Аnnu. Rev. Phytopathol. 10: 375-398.

Odebode, A.C. 2006. Control of post-harvest pathogens of fruits by culture filtrate from antagonistic fungi. Journal of Plant Protection Research. 46(1).

Prasad, B.N. and Kumar, M.R. 2011. Effect of non-volatile compounds produced by Trichoderma spp. on growth and sclerotial viability of Rhizoctonia solani, Incitant of sheath blight of Rice. Indian Journal of fundamental and Applied Life Sciences. 1(2): 37-42.

Ratnakumari, K., Nagamani, A., Bhramaramba, R., Kumar, R., Kumar, U and Shaik, M. 2011. Non-volatile and volatile metabolites of antagonistic Trichoderma against collar rot pathogen of menthe arvensis. Int. J Pharm Biomed Res. 2(2): 56-58.

Rodriguez-Kabana, R. and Curl, E.A. 1980. Non- target effect of pesticides on soil borne pathogens and disease. Annu. Rev. Phytopathol. 17: 311-312.

Sivasithamparam, K and Ghisalberti, EL. 1998. Secondary metabolism in Trichoderma and Gliocladium. In: Trichoderma and Gliocladium. Harman GE, Kubicek, CP (ed.). Taylor and Francis, London. pp. 139-191.

Vinale, F., Sivassithamparam, K., Ghisalberti, EL., Marra, R., Woo, S.L. and Lorito, M. 2008. Trichoderma-plant-pathogen interactions. Soil Boil. Biochem. 40:1-10.

\section{How to cite this article:}

Pranab Dutta, P. Bhowmick and Boruah, S. 2018. Effect of Extracellular Metabolites of Trichoderma pseudokoningii on Radial Growth of Fusarium oxysporum, Colletotrichum capsici, Rhizoctonia solani and Sclerotinia sclerotiorum. Int.J.Curr.Microbiol.App.Sci. 7(01): 874-879. doi: https://doi.org/10.20546/ijcmas.2018.701.106 